\title{
SPORT-ANTHROPOLOGICAL INVESTIGATION ON GERMAN MALE VOLLEYBALL PLAYERS OF DIFFERENT PERFORMANCE CLASSES AND DIFFERENT GAME POSITIONS
}

\author{
Christoph Raschka, Corina Dierer \\ Institute of Sports Sciences, Julius Maximilian University Würzburg, Germany
}

\begin{abstract}
The present study deals with sports anthropological comparison of the physique of 28 male volleyball players from higher $(n=13)$ and lower $(n=13)$ game classes and different game positions. As a result, higher Parnell endomorphism values can be recognized in the lower classes. Vice versa, a tendency to significantly higher values was found in the higher game classes for body height, stylion height, gnathion height, tibia height, AKS index and ectomorphism according to Parnell. In the somatochart, the attackers were slightly more endomorphic, the minor attackers a little more mesomophic. The highclass players had higher ectomorphism values, the low-class players higher endomorphism values. In the constitutional typology according to Knussmann, the subjects were on average subleptomorphic and submacrosomic, according to Conrad rather hyperplastic and leptomorphic. In a follow-up study, the number of subjects should be increased to enable a differentiated analysis of game positions.
\end{abstract}

Keywords: volleyball; sports anthropology; somatotyping; kinanthropometry; somatotypes

\section{INTRODUCTION}

Volleyball is a team sport in which two teams of six players are separated by a net. There are different positions filled on every volleyball team at different levels (setter, outside hitter / left side hitter, middle hitter, opposite hitter / right 
side hitter and libero / defensive specialist). Each of these positions plays a specific role in winning a volleyball match.

In their excellent studies, the working group around Prof. Dr. Kaarma and her daughter Dr. R. Stamm [19-26] has so far drawn a comprehensive sports anthropological picture of the Estonian volleyball player. In a series of followup studies, they also succeeded in establishing the Estonian constitution type system in the field of sports anthropology and sports science [19-26].

In this explorative work, we try to make the first cautious step in the physique analysis of German male volleyball players.

\section{PARTICIPANTS AND METHODS}

The present study examines anthropometric and somatotypical differences between male volleyball players of different performance classes and game positions.

Hessian volleyball players from hobby players to the Hessen league level were recorded as players of the lower performance level (low class). As a high level of performance (high class), players from the association league level to the German top league level were summarized.

All center blockers (position 3) and outside attackers (position 4) were defined as attackers. All other athletes were grouped as minor attackers.

The age of the test subjects was between 16 and 53 years (average age 27.2 years).

Each proband participated voluntarily and the data were used anonymously.

Anthropometric data and computed constitutional and somatotypical parameters in this work correspond to international standards $[1,3,5,6,8,9$, $10,12,15,16,27,28]$. The analysis of differences was tested by ANOVA.

\section{RESULTS}

All the collected anthropometric parameters are listed in the following table. 


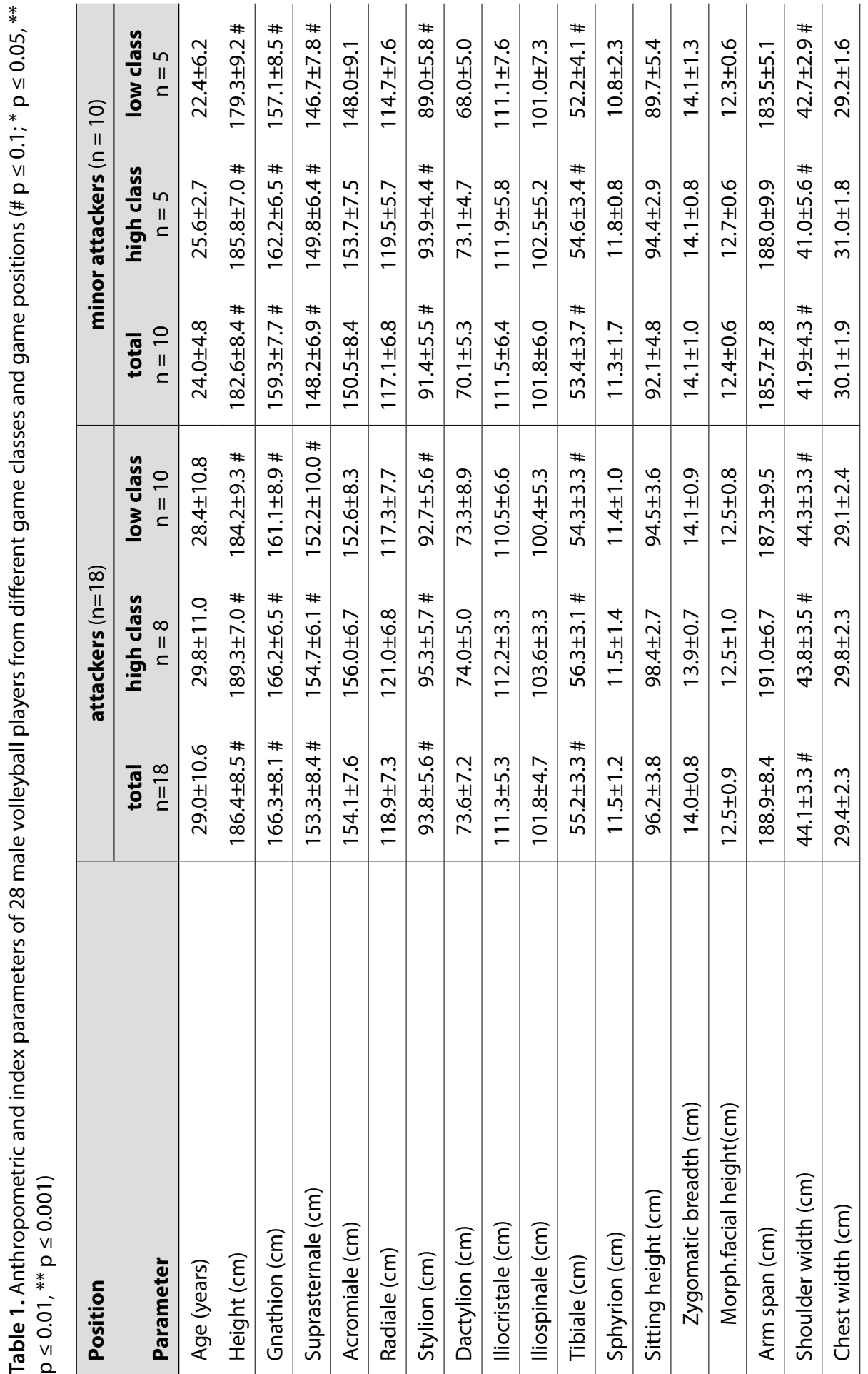




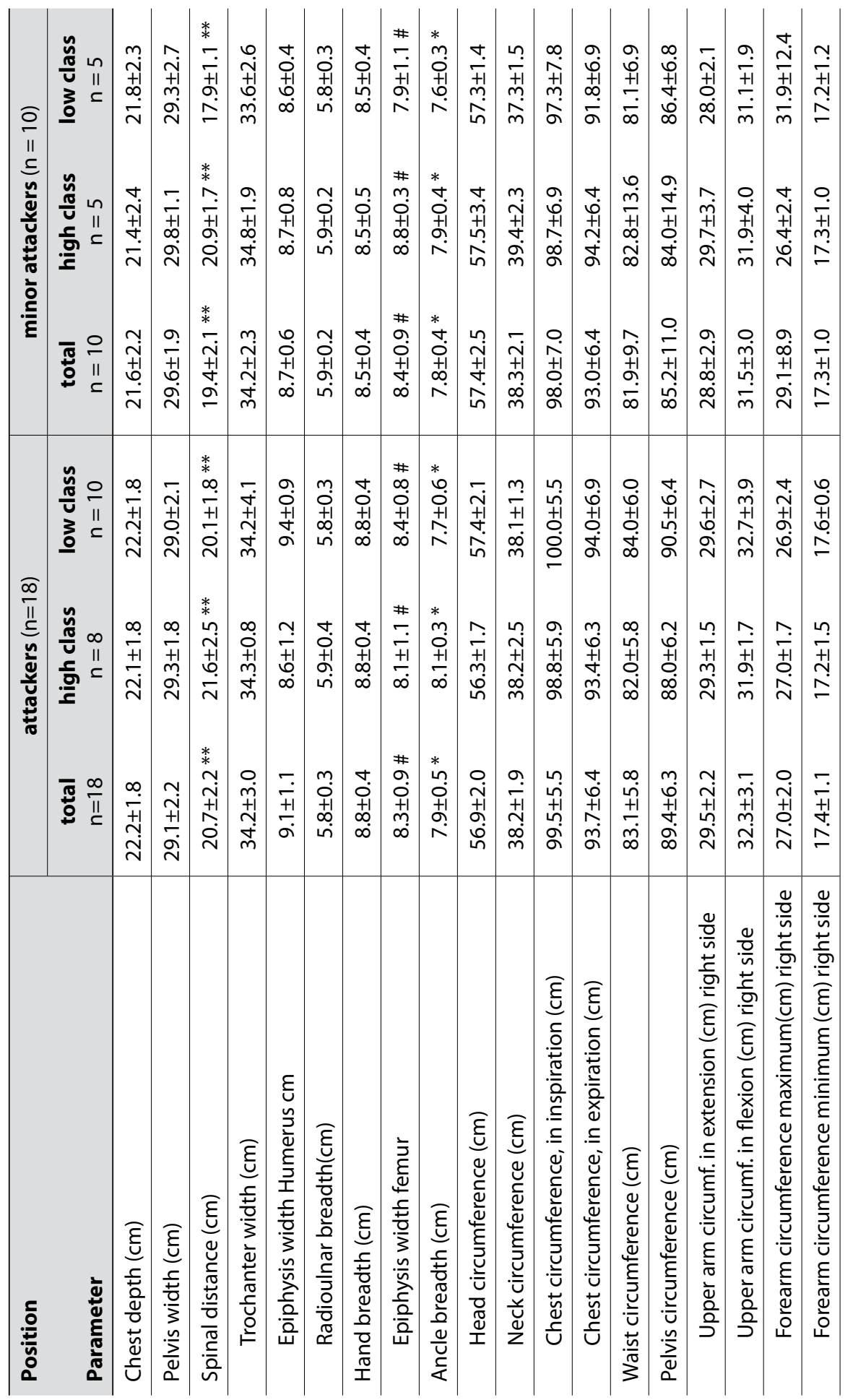




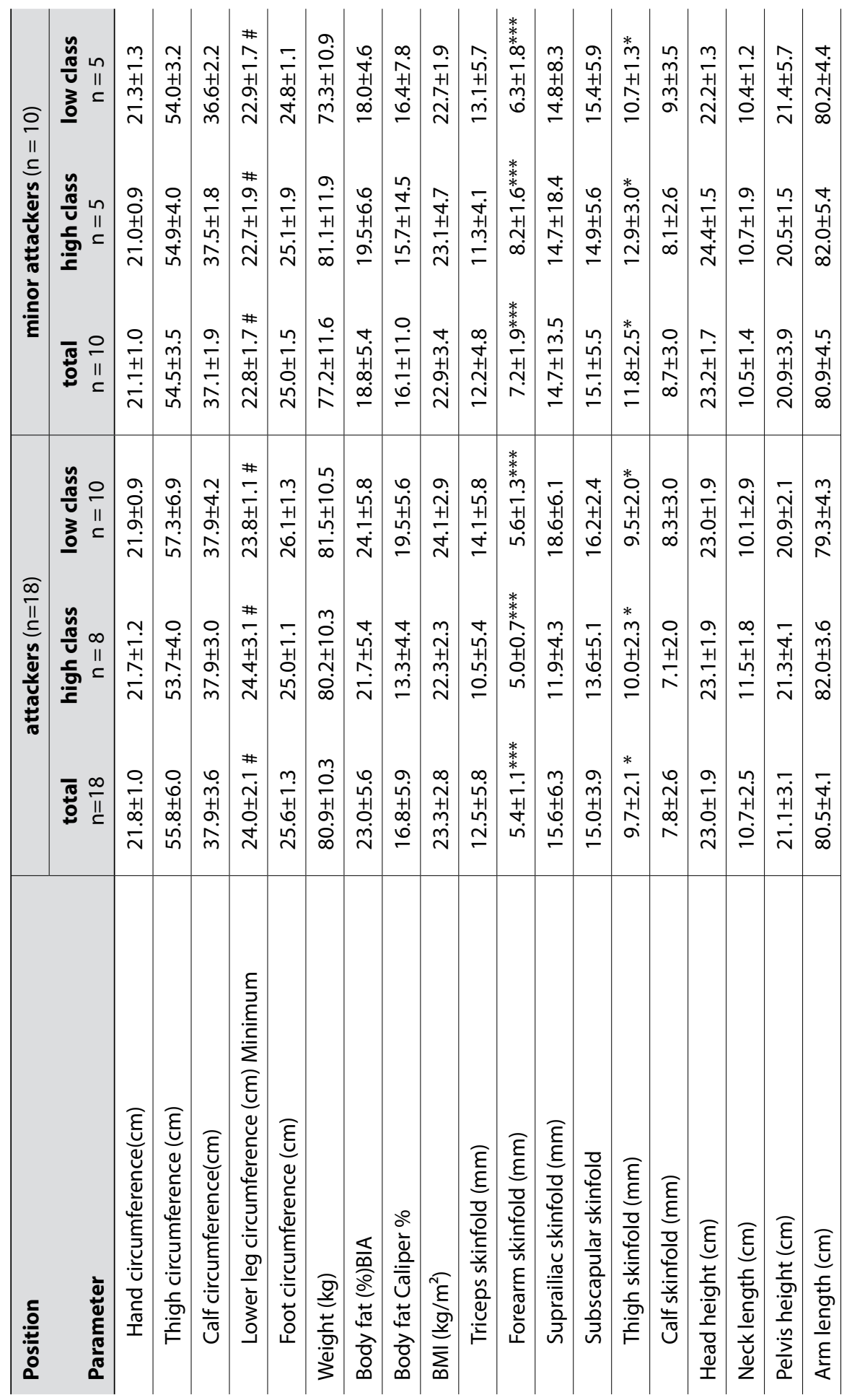




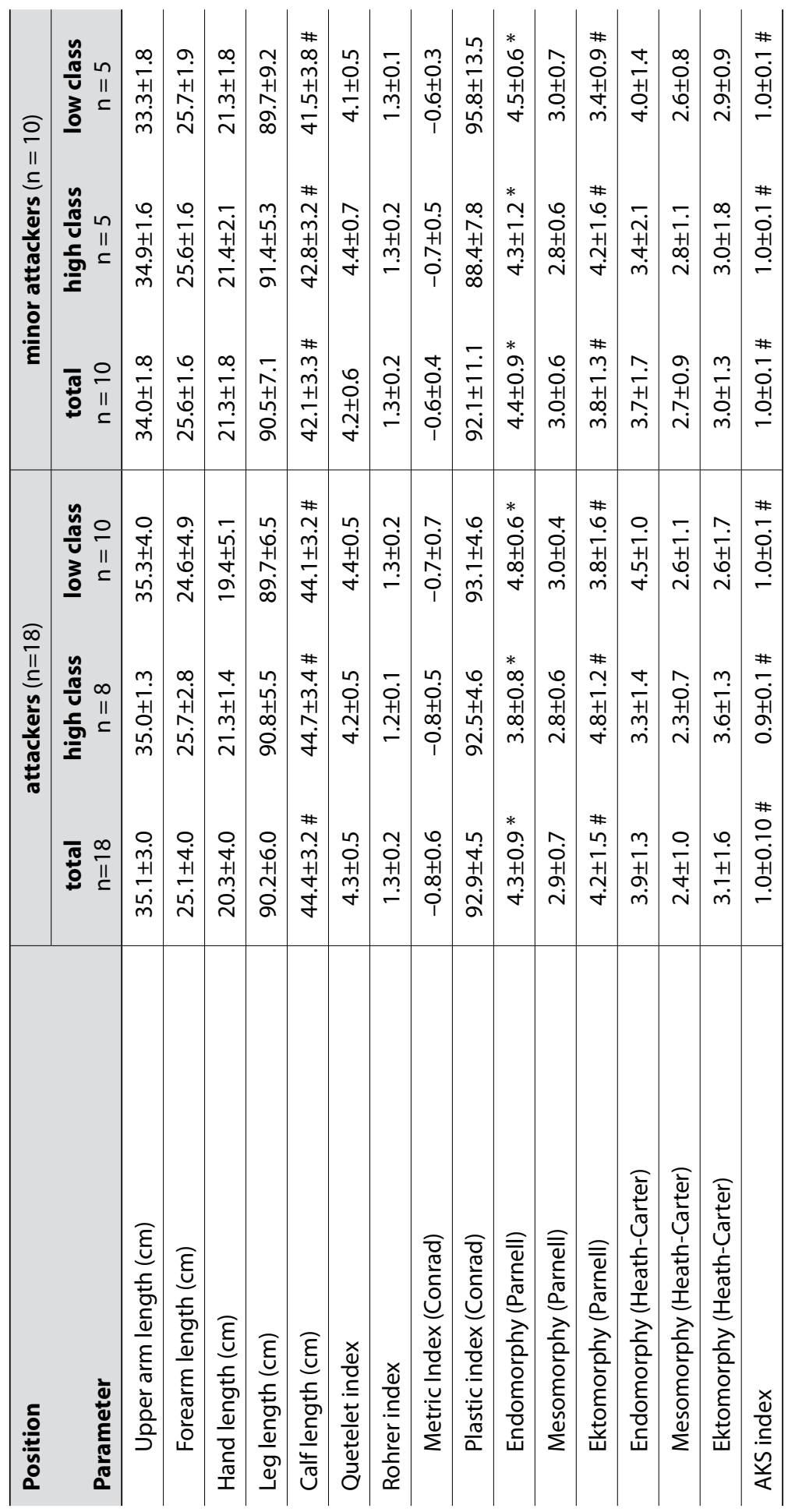


Generally, the attackers and the players of higher classes have almost significantly ( $\mathrm{p} \leq 0.1$ ) higher values for the following parameters: height, gnathion, suprasternale, stylion, tibiale, shoulder width, spinal distance, lower leg circumference (minimum) and calf length. The following parameters were significantly higher: spinal distance $(\mathrm{p} \leq 0.01)$ and ankle breadth $(\mathrm{p} \leq 0.05)$.

For the skin fat folds, the attackers had significantly lower values for the forearm $(\mathrm{p} \leq 0.001)$ and the thigh $(\mathrm{p} \leq 0.05)$.

Somatotyping according to Parnell [15] resulted in significantly lower values $(\mathrm{p} \leq 0.05)$ for endomorphy in attackers and higher game classes as well as almost significantly $(\mathrm{p} \leq 0.1)$ higher ectomorphism values in attackers and higher classes.

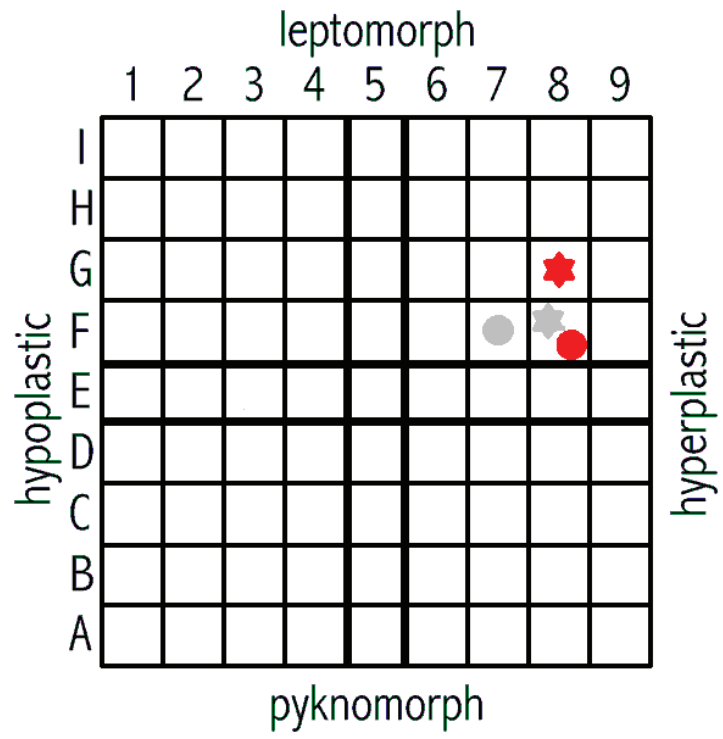

Figure 1. Mean constitutional types of higher-class attackers (red star) and lower-class attackers (grey star), higher-class minor attackers (red circle) and lower-class minor attackers (grey circle) in the chessboard pattern graphic after Conrad [3].

In the chessboard pattern graphic after Conrad [3], the mean values of all the four groups are in the hyperplastic-leptomorphic quadrant. 


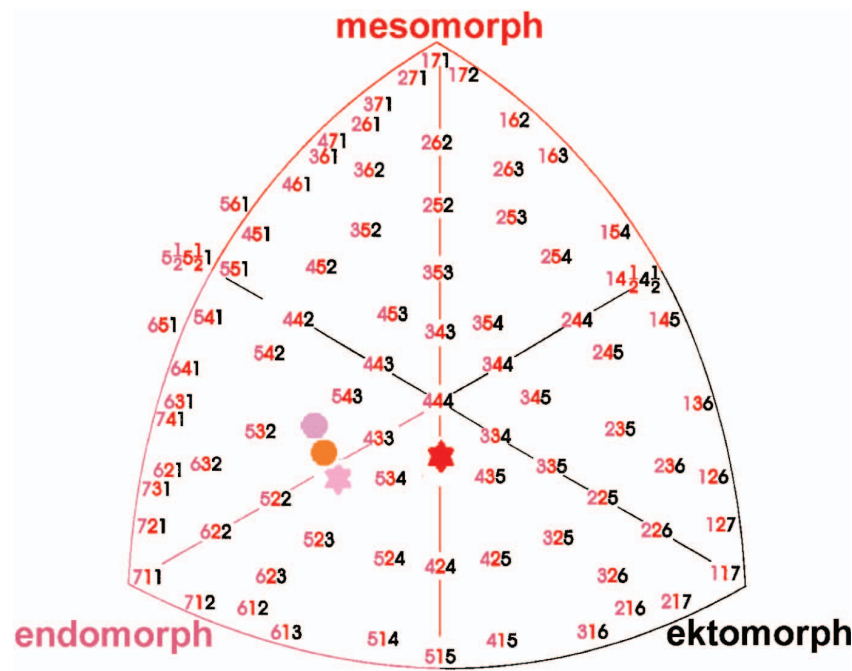

Figure 2. Mean somatotypes of higher-class attackers (red star) and lower-class attackers (pink star), higher-class minor attackers (red circle) and lower-class minor attackers (pink circle) in the somatochart after Parnell [15].

The Parnell somatochart [15] shows the mean of the attackers on the mesomorphia axis below the center and the other three samples in the endomorphia area.

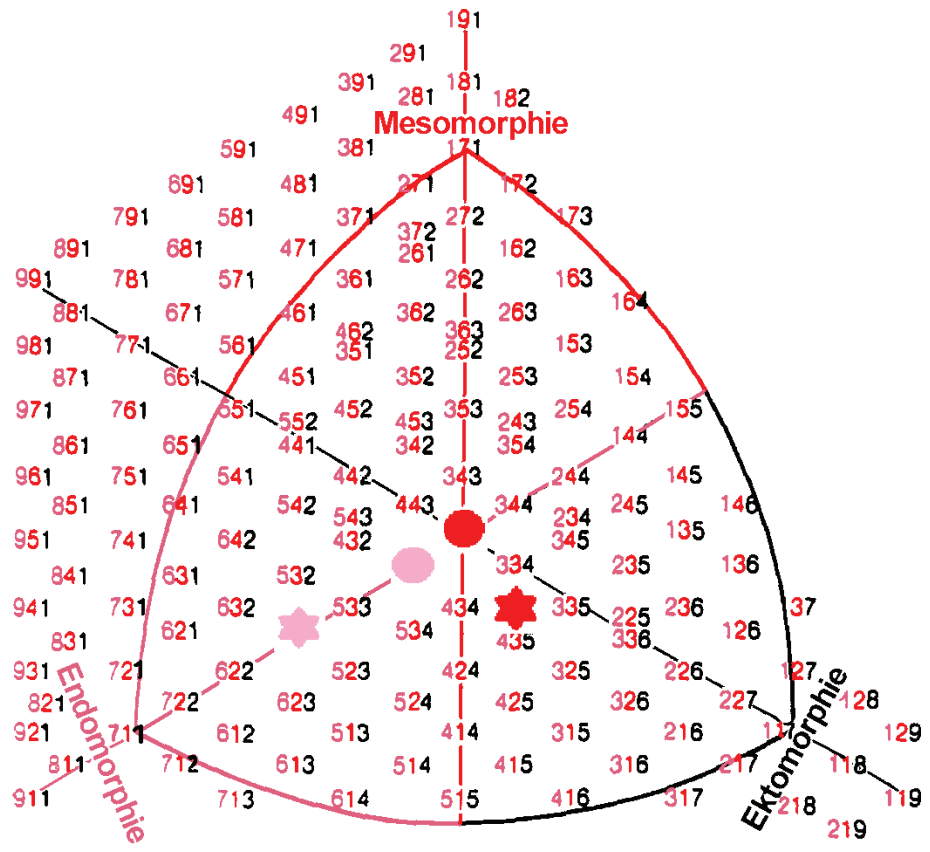

Figure 3. Mean somatotypes of higher-class attackers (red star) and lowerclass attackers (pink star), higher-class minor attackers (red circle) and lower-class minor attackers (pink circle) in the somatochart after Heath and Carter [5, 6] 
In the Heath-Carter somatochart $[5,6]$, the mean for the higher-class attackers is found as the only one in the ectomorphic area, on the right below the centre. The mean values of the other three samples are all on the endomorphism axis, with the higher-class non-attackers even being in the centre.

\section{DISCUSSION}

The average height of the volleyball players examined was $185 \mathrm{~cm}$. This is consistent with the results of McArdle et al. [13]. They reported an average body height of $185.3 \pm 10.2 \mathrm{~cm}$ in 11 volleyball players. When Olympic volleyball players were compared [17], their body height rose continuously from Tokyo in 1964 with $189.4 \mathrm{~cm}$ over Munich 1972 with $192 \mathrm{~cm}$ to Montreal 1976 with $195 \mathrm{~cm}$ [14]. According to Reilly [17], the England team had an average height of $185.5 \mathrm{~cm} \pm 6.2 \mathrm{~cm}$ in 1980 . The Canadian national team had an average height of $188.9 \pm 4.2 \mathrm{~cm}$ [2]. The international volleyball players measured by Maas [11] also had an average height of $185.8 \mathrm{~cm}$. Even Tittel and Wutscherk [28] put the height of volleyball players at $187.8 \mathrm{~cm}$. The minor attackers (libero, diagonal player, pass player) were generally nearly significantly smaller than the attackers. The situation with the acromion was similar to that with the body heights. In 1974 Maas [11] determined an acromiale height of $152.9 \mathrm{~cm}$, a suprasternale height of $151.9 \mathrm{~cm}$, an iliocristale height of $113.9 \mathrm{~cm}$, an iliospinale height of $107.3 \mathrm{~cm}$, a tibiale heigth of $50.7 \mathrm{~cm}$ and a sitting height of $96.1 \mathrm{~cm}$. Tittel and Wutscherk [28] gave a value of $48.8 \mathrm{~cm}$ for the tibiale. While Norton and Olds [14] calculated a relative sitting height value of $51 \%$ of the total body height for their volleyball players, the present study shows an almost identical value of $51.1 \%$. In general, there are clear congruencies in all the examined samples.

Similarly to the present study, according to Tittel and Wutscherk [28], the arm span of volleyball players was $191.7 \mathrm{~cm}$ - above the respective body height, which speaks for long arms. The foot length of volleyball players averaged $25.6 \mathrm{~cm}$ according to Scholl [18], $27.3 \mathrm{~cm}$ according to Tittel and Wutscherk [28], $27.8 \mathrm{~cm}$ according to Maas [11], and is therefore the same as that determined in the present study $(27.8 \mathrm{~cm})$. While Maas [11] determined a shoulder width of $40.4 \mathrm{~cm}$, Tittel and Wutscherk [28] measured a value of $40 \mathrm{~cm}$ for volleyball players. In the present study, the chest depth was above that of the volleyball players of Maas [11] at $20.4 \mathrm{~cm}$. Conversely, the spinal distances of the volleyball players of Maas [11] were with $24.4 \mathrm{~cm}$ above those of the present survey. 
At $8.7 \mathrm{~cm}$, the hand width of the study by Maas [11] is similar to that of the current survey.

In comparison to Maas [11], the circumferences were similar to that of the current study: neck circumference $(37.4 \mathrm{~cm})$, chest circumference $(101.4 \mathrm{~cm})$, flexed $(31.8 \mathrm{~cm})$ and relaxed upper arm circumference $(28.8 \mathrm{~cm})$, forearm $(27 \mathrm{~cm})$, thigh $(55.8 \mathrm{~cm})$ and lower leg $(36.3 \mathrm{~cm})$. In comparison, Tittel and Wutscherk [28] reported the following circumferential measurements for their volleyball players: chest circumference inspiratory $103.3 \mathrm{~cm}$, expiratory $95.4 \mathrm{~cm}$, upper arm $29.9 \mathrm{~cm}$, thigh $56.8 \mathrm{~cm}$ and lower leg $38.4 \mathrm{~cm}$.

According to Scholl [18], even 17-year-old volleyball players had a chest circumference of $90 \pm 5 \mathrm{~cm}$.

Norton [14] gives an average weight of $90 \mathrm{~kg}$ for elite volleyball players. According to Reilly [17], Olympic volleyball players had the following average body weight values: Tokyo (1964) $84.3 \mathrm{~kg}$, Munich (1972) $85.5 \mathrm{~kg}$, Montreal (1976) $88 \mathrm{~kg}$.

The volleyball players measured by McArdle et al. [13] weighed $78.3 \pm 12 \mathrm{~kg}$, those measured by Tittel and Wutscherk [28] weighed $81.3 \mathrm{~kg}$. According to Driskel and Wolinsky [4], the body weights of volleyball players were between the 75th and 90th percentiles.

Reilly [17] states a body fat percentage of $10.5-14 \%$ for elite volleyball players.

Because amateur athletes were also examined in the present study, there is a wider range here.

The following somatotypes were found in HC somatotyping in this study: $3.9-2.5-3$.

Ackland et al. [1] received the values of $2.5-4.5-3.5$ for good volleyball players and $1.9-4.7-3.6$ for the US national team. The following additional somatotypes values were reported for elite volleyball players: $2.5-5.4-2.6$ [2], $3-5-3$ [9] and $2.3-4.4-3.3$ [14].

While the average arm length in the present study was $80.6 \mathrm{~cm}$, Scholl [18] and Tittel and Wutscherk [28] put the arm lengths of their volleyball players at $65-87 \mathrm{~cm}$ and $83.2 \mathrm{~cm}$, respectively. The upper arm length in the current study at $34.8 \mathrm{~cm}$ was slightly below the volleyball players of Scholl [18] at $23-37 \mathrm{~cm}$, Tittel and Wutscherk [28] at $36.7 \mathrm{~cm}$ and Maas [11] at $35.8 \mathrm{~cm}$. Naturally, this depends on the respective performance level.

With regard to the length of the forearm, the values of the present study were below the values of Maas [11] with an average of $27.3 \mathrm{~cm}$, Tittel and Wutscherk [28] with $26.2 \mathrm{~cm}$ and Scholl [18] with $25.3 \mathrm{~cm}$. For the hand lengths, Tittel and Wutscherk [28] documented an average of $20.3 \mathrm{~cm}$ and 
Scholl [18] $19.5 \mathrm{~cm}$. While the average leg length in the present study was $90.3 \mathrm{~cm}$, Tittel and Wutscherk [28] reported the values of $92.8 \mathrm{~cm}$ and Scholl [18] $89 \mathrm{~cm}$. The average lower leg values for the present study were $43.3 \mathrm{~cm}$, for Tittel and Wutscherk [28] $42.2 \mathrm{~cm}$ and for Scholl [18] $37.2 \mathrm{~cm}$.

While the Rohrer index averaged 1.26 in the present study, Scholl's [28] volleyball players had a value of 1.58 . The taller the players were, the lower were the values of the Rohrer index in our study. Tittel and Wutscherk [28] found an AKS index of 1.07 for their volleyball players.

The present exploratory study confirmed the assumption of a tendential difference in the physique of volleyball players of different levels and positions.

It is therefore intended to conduct a more comprehensive survey with significantly more test subjects so that the different game positions no longer have to be summarized but can be viewed in a more differentiated manner.

\section{REFERENCES}

1. Ackland T.R., Elliott B., Bloomfield J. (2008). Applied anatomy and biomechanics in sport. Champaign: Human Kinetics.

2. Carter L.J.E., Heath B.H. (1990). Somatotyping - development and applications. Cambridge: University Press.

3. Conrad K. (1963). Der Konstitutionstypus. Berlin: Springer Verlag.

4. Driskell J.D., Wolinsky I. (2002). Nutritional assessment of athletes. Boca Raton: CRC Press.

5. Heath B.H., Carter L.J.E. (1967). A modified somatotype method. Am J Phys Anthrop, 27, 57-74. https://doi.org/10.1002/ajpa.1330270108

6. Heath B.H., Carter L.J.E. (1990). Somatotyping - development and applications. Cambridge Studies in Biological Anthropology. Great Britain: Redwood Press.

7. Hirata K.-I. (1979). Selection of Olympic champions. Toyota (Japan): Chukyo University Press.

8. Knußmann R. (1996). Vergleichende Biologie des Menschen. Lehrbuch der Anthropologie. Stuttgart: Gustav Fischer Verlag.

9. Král J., Novotný V. (1970). Physical fitness and its laboratory assessment: proceedings of the conference on laboratory assessment of physical fitness organized in Prague July 1-3, 1968. Prague: Universitas Carolina Pragenis.

10. Kretschmer E. (1921). Körperbau und Charakter. Berlin: Springer Verlag.

11. Maas G.D. (1974). The physique of athletes. An anthropometric study of 285 sportsmen from 14 sports in a total of 774 athletes. Leiden: University Press.

12. Martin R., Knussmann R. (1988). Anthropologie. Handbuch. Band I. Stuttgart: Fischer Verlag. 
13. McArdle W.D., Katch V.L., Rieth N., Dehaye P. (2004). Nutritions et performances sportives. Brüssel: Editions De Boeck Université.

14. Norton K., Olds T. (Australian Sports Commission 1996). Anthropometrica: a textbook of body measurement for sports and health courses. Sydney: UNSW Press.

15. Parnell R.W. (1954). Somatotyping by physical anthropometry. Am J Phys Anthrop, 12, 209-239. https://doi.org/10.1002/ajpa.1330120218

16. Raschka C. (2006). Sportanthropologie. Köln: Sportverlag Strauß.

17. Reilly Th. (International Society for Advancement of Kinanthropometry) (1990). Kinanthropometry VIII: proceedings of the $8^{\text {th }}$ International Conference of the International Society for the Advancement of Kinanthropometry (ISAK). Florence: Routledge.

18. Scholl H. (1986). Kondition und Körperbau jugendlicher Sportspieler. Hamburg: Cwalina.

19. Stamm R., Stamm M., Jairus A., Toop R., Tuula R., Joao P.V. (2017). Do height and weight play an important role in block and attack efficiency in high-level men's volleyball? Papers on Anthropology, 26(1), 64-71.

https://doi.org/10.12697/poa.2017.26.1.05

20. Stamm R., Stamm M., Koskel S. (2002). Age, body build, physical ability, volleyball technical and psychophysiological tests and proficiency at competition in young female volleyballers (aged 13-16 years). Papers on Anthropology, 11, 253-282.

21. Stamm R., Stamm M., Oja A. (2000). A system for recording volleyball games and their analysis. Int. J. Volleyball Res., 2(1), 18-22.

22. Stamm R., Stamm M., Torilo K., Thomson K., Jairus A. (2016). Comparative analysis of the elements of the attack and defence in men's and women's games in the Estonian volleyball highest league. Papers on Anthropology, 25(1), 37-54. https://doi.org/10.12697/poa.2016.25.1.04

23. Stamm R., Stamm M., Pähn M., Jairus A. (2015). Comparison of the body build and physical abilities of the students of sports classes and ordinary classes. Papers on Anthropology, 24(2), 102-113. https://doi.org/10.12697/poa.2015.24.2.09

24. Stamm R., Stamm M., Vantis M., Jairus A. (2016). Comparative analysis of serve and serve reception performance in pool B of European Men's Volleyball Championship 2015. Papers on Anthropology, 25(2), 55-69. https://doi.org/10.12697/poa.2016.25.2.06

25. Stamm R., Veldre G., Stamm M., Kaarma H., Koskel S. (2001). Young female volleyball players' anthropometric characteristics and volleyball proficiency. Int. J. Volleyball Res., 4(1), 8-11.

26. Stamm R., Veldre G., Stamm M., Thomson K., Kaarma H., Loko J., Koskel S. (2003). Dependence of young female volleyballers' performance on their body 
build, physical abilities, and psycho-physiological properties. J. Sports Med. Phys. Fitness, 43, 431-439.

27. Štěpnička J. (1972). Typological and motor characteristics of athletes and university students. Prague: Charles University Press.

28. Tittel K., Wutscherk H. (1972). Sportanthropometrie. Leipzig: Barth.

\section{Adress for correspondence}

Christoph Raschka

Institute of Sports Sciences

Julius-Maximilians-University

Judenbühlweg 11, D-97082 Würzburg, Germany

E-mail: christoph.raschka@uni-wuerzburg.de 